\title{
Kajian Tingkat Kebisingan Komplek Permukiman di Ruang Peruntukan \\ Perdagangan Dan Jasa Di Kota Jambi.
}

\section{Guntar Marolop S.}

\begin{abstract}
Merujuk pada Rencana Tata Ruang Wilayah Kota Jambi Tahun 2013-2033, salah satu ruang peruntukan perdagangan dan jasa di kota Jambi adalah di jalan Prof. Dr. Soemantri Brojonegoro Kelurahan Solok Sipin Kota Jambi yang diambil sebagai lokasi penelitian mewakili Kota Jambi. Namun, pada ruang tersebut terdapat komplek permukiman. Dengan demikian bila di ruang peruntukan perdagangan dan jasa terdapat permukiman, maka baku mutu lingkungan tingkat kebisingan cenderung melampaui baku mutu tingkat kebisingan permukiman, yakni > $55 \mathrm{~dB}(\mathrm{~A})$.

Untuk mengkaji tingkat kebisingan dilingkungan permukiman yang berada pada wilayah peruntukan perdagangan dan jasa merujuk ke Keputusan Menteri Lingkungan Hidup Nomor : 48/MENLH/XI/1996 Tentang Baku Tingkat Kebisingan yaitu Parameter kebisingan Ekivalen $\left(\mathrm{L}_{\mathrm{eq}}\right)$, kebisingan rata-rata $\left(\mathrm{L}_{\mathrm{evg}}\right)$, kebisingan minimum $\left(\mathrm{L}_{\min }\right)$, dan kebisingan maksimum $\left(\mathrm{L}_{\max }\right)$.

Tingkat kebisingan di komplek permukiman Kota Jambi yang terletak di ruang peruntukan perdagangan dan jasa sudah di atas baku mutu lingkungan, yakni : 1 . Tingkat Kebisingan Ekivalen $=62,4 \mathrm{~dB}(\mathrm{~A}) ; 2$. Tingkat Kebisingan Rata-rata=62,2 $\mathrm{dB}(\mathrm{A})$; 3. Tingkat Kebisingan Minimum $=60,2 \mathrm{~dB}(\mathrm{~A})$; dan 4. Tingkat Kebisingan Maksimum $=64,3 \mathrm{~dB}(\mathrm{~A})$
\end{abstract}

Key words : Permukiman, Perdagangan dan jasa, tingkat kebisingan.

\section{PENDAHULUAN}

Merujuk pada RTRW Kota Jambi Tahun 2013-2033, salah satu ruang peruntukan perdagangan dan jasa di kota Jambi adalah di jalan Prof. Dr. Soemantri Brojonegoro Kelurahan Solok Sipin Kota Jambi yang diambil sebagai lokasi penelitian mewakili Kota Jambi. Namun, pada ruang tersebut juga terdapat komplek permukiman. Dengan adanya pembagian peruntukan ruang sesuai dengan RTRW Kota Jambi tersebut, maka baku mutu lingkungan yang diberlakukan di ruang itu disesuaikan dengan peraturan perundang-undangan yang berlaku. Dengan demikian bila suatu kegiatan ditempatkan pada suatu ruang peruntukan yang tidak sesuai, maka ada dua hal yang mungkin terjadi yaitu :

1. Pemerintah Daerah tidak memberikan izin pada kegiatan dimaksud,

2. Bila harus berada pada ruang yang bukan peruntukannya, maka baku mutu lingkungannya tidak sesuai dengan yang seharusnya, sehingga akan menimbulkan dampak negatif terhadap manusia yang berada di ruang tersebut. 
Ditinjau dari RTRW Kota Jambi Tahun 2013-2033, banyak ditemukan komplek permukiman yang tidak berada pada ruang peruntukan permukiman, tetapi terdapat di ruang peruntukan lain seperti di ruangperuntukan perdagangan dan jasa.

Dari latar belakang di atas, maka masalahnya yang dikaji dalam penelitian ini adalah apakahtingkat kebisingan yang terpapar di permukiman yang berada pada peruntukan perdagangan dan jasa masih sesuai baku mutu yakni $55 \mathrm{~dB}$. Bila baku mutu tingkat kebisingannya telah melebihi, pengelolaan yang bagaimana yang harus dilakukan untuk meminimalkan tingkat kebisingan tersebut.

Tujuan penelitian adalah a). Untuk mengetahui tingkat kebisingan yang terpapar di permukiman yang berada pada peruntukan perdagangan dan jasa; dan b). Memberikan solusi upaya pengelolaan yang harus dilakukan untuk meminimalkan tingkat kebisingan.

Manfaat dilaksanakannya penelitian ini maka diharapkan dapat menjadi bahan masukan bagi Pemerintah dalam upaya pembinaan pengendalian kebisingan di permukiman di ruang peruntukan perdagangan dan jasa serta dapat membantu masyarakat, khususnya masyarakat yang bermukim di wilayah peruntukan perdagangan dan jasa di Kota Jambi agar mengerti melakukan upaya pengendalian kebisingan di permukimannya.

\section{METODE PENELITIAN}

Data kebisingan akan diperoleh dari pengukuran langsung di lapangan dan selanjutnya dianalisis di laboratorium. Jenis data kebisingan merupakan data primer.

Lokasi pengambilan sampel dipusatkan pada lokasi permukiman pada jam sibuk yang diperkirakan mengalami dampak dari berbagai kegiatan di ruang perdagangan dan jasa. Mewakili kota Jambi, lokasi permukiman yang dipilih adalah di RT 11 Kelurahan Solok Sipin dengan koordinat LS : 1 ${ }^{\circ} 36^{\prime} 12.54$ " dan BT : $103^{\circ} 3602.68^{\prime \prime}$.

Waktu pengukuran dilakukan pada saat jam sibuk. Pengukuran tingkat kebisingan yang dilakukan dalam penelitian ini hanya sesaat yakni pada hari Kamis 14 Juli 2016 siang hari jam 14.00 WIB selama 30 menit yang diperkirakan merupakan jam sibuk, sesuai KepMen Lingkungan Hidup Nomor : 48 Tahun 1996.

Alat yang digunakan dalam melakukan dan metode pengukuran kebisingan adalah seperti pada Tabel 1 . 
Tabel 1. Alat dan Metode Pengukuran Kebisingan.

\begin{tabular}{|r|l|c|c|l|}
\hline No. & \multicolumn{1}{|c|}{ Parameter } & Satuan & Baku Mutu & \multicolumn{1}{|c|}{ Metode/Alat } \\
\hline 1 & Suhu & ${ }^{\circ} \mathrm{C}$ & - & Thermometer \\
\hline 2 & Kelembaman & $\%$ & - & Hygrometer \\
\hline 3 & Kecepatan Angin & knot & - & Anemometer \\
\hline 4 & Kebisingan & $\mathrm{dB}$ & 55 & Sound Level Meter \\
\hline
\end{tabular}

Metode pengumpulan data kebisingan dilakukan sesuai dengan SNI 7570:2010.

Parameter kebisingan yang diukur adalah Tingkat kebisingan Ekivalen $\left(\mathrm{L}_{\mathrm{eq}}\right)$, tingkat kebisingan rata-rata $\left(\mathrm{L}_{\mathrm{evg}}\right)$, tingkat kebisingan minimum $\left(\mathrm{L}_{\mathrm{min}}\right)$, dan tingkat kebisingan maksimum $\left(\mathrm{L}_{\max }\right)$.

Metode analisis data untuk memperkirakan tingkat kebisingan adalah dengan menguji data yang terukur di lapangan di laboratorium. Hasil uji laboratorium yang diperoleh adalah parameter kebisingan merujuk ke Keputusan Menteri Lingkungan Hidup Nomor : 48/MENLH/XI/1996 Tentang Baku Tingkat Kebisingan yaitu Parameter kebisingan Ekivalen $\left(\mathrm{L}_{\mathrm{eq}}\right)$, kebisingan rata-rata $\left(\mathrm{L}_{\mathrm{evg}}\right)$, kebisingan minimum $\left(\mathrm{L}_{\mathrm{min}}\right)$, dan kebisingan maksimum $\left(\mathrm{L}_{\max }\right)$.

\section{HASIL DAN PEMBAHASAN}

Lokasi permukiman RT 11 berjarak \pm 100 meter dari jalan Prof. Dr. Soemantri Brojonegoro. Tingkat kebisingan di komplek permukiman warga RT 11 Kelurahan Solok Sipin adalah seperti pada Tabel 4.1 di bawah (sesuai dengan hasil laboratorium)

Tabel 2 Hasil Pengukuran Tingkat Kebisingan di RT 11 Kelurahan Solok Sipin.

\begin{tabular}{|c|c|c|c|c|c|}
\hline No. & Paramter & $\begin{array}{l}\text { Lokasi } \\
\text { RT } 11\end{array}$ & $\begin{array}{l}\text { BML/ } \\
E Q S^{*}\end{array}$ & $\begin{array}{l}\text { Satuan/ } \\
\text { Unit }\end{array}$ & $\begin{array}{l}\text { Metode/ } \\
\text { Method }\end{array}$ \\
\hline 1 & $\begin{array}{l}\text { Tingkat Kebisingan Ekivalen/ } \\
\text { Noise Level (Equivalent), } \mathrm{L}_{\mathrm{eq}}\end{array}$ & 62,4 & \multirow{4}{*}{55} & \multirow{4}{*}{$\mathrm{dB}(\mathrm{A})$} & \multirow{4}{*}{$\begin{array}{c}\text { SNI } \\
7231: 2009\end{array}$} \\
\hline 2 & $\begin{array}{l}\text { Tingkat Kebisingan Rata-rata/ } \\
\text { Noise Level (Average), } \mathrm{L}_{\mathrm{avg}}\end{array}$ & 62,2 & & & \\
\hline 3 & $\begin{array}{l}\text { Tingkat Kebisingan Minimum/ } \\
\text { Noise Level (Minimum), } \mathrm{L}_{\min }\end{array}$ & 60,2 & & & \\
\hline 4 & $\begin{array}{l}\text { Tingkat Kebisingan Maksimum/ } \\
\text { Noise Level (maximum), } \mathrm{L}_{\max }\end{array}$ & 64,3 & & & \\
\hline
\end{tabular}

Tingkat kebisingan yang terukur di permukiman RT 11 Kelurahan Solok Sipin bersumber dari berbagai sumber bising. Sumber tingkat kebisingan didominasi dari kenderaan bermotor yang lalulalang dijalan Prof. Dr. Soemantri Brojonegoro. 
Namum, dalam penelitian ini tidak dilakukan inventarisasi jenis dan jumlah kenderaan bermotor yang melintas di seputar lokasi penelitian, sehingga tidak tersedia data mengenai jumlah dan jenis kenderaan tersebut dan tidak dapat dikorelasikan dengan tingkat kebisingan yang terjadi.

Mencermati hasil penelitian tingkat kebisingan di lokasi penelitian seperti pada Tabel 2 di atas, secara umum dapat dikemukakan bahwa tingkat kebisingan di permukiman RT 11 Kelurahan Solok Sipin telah melebihi baku mutu lingkungan yang diperbolehkan menurut PermenLH No. 48 Tahun 1996. Semua parameter tingkat kebisingan telah melebihi $55 \mathrm{~dB}(\mathrm{~A})$.

Lalu lintas di jalan Prof. Dr. Soemantri Brojonegoro Kelurahan Solok Sipin Kota Jambi merupakan sumber utama kebisingan, karena kegiatan lain di lokasi penelitian hanyalah Hotel, Rumah sakit dan beberapa pasar modern. Bunyi yang ditimbulkan oleh lalu lintas adalah bunyi dengan tingkat suara yang tidak konstan, hal ini terlihat dari bervariasinya tingkat kebisingan $\left(\mathrm{L}_{\min }=60,2 \mathrm{~dB}(\mathrm{~A})\right.$ dan $\mathrm{L}_{\max }=64,3 \mathrm{~dB}(\mathrm{~A})$. Variasi tingkat kebisingan ini diduga bersumber dari sejenis kegiatan yaitu jalanan pada umumnya. Dugaan ini didasarkan dari pendapat Higiene Perusahaan dan Kesehatan Kerja tentang intensitas kebisingan dan sumbernya. Dalam Higiene Perusahaan dan Kesehatan Kerja tersebut dijelaskan bahwa kebisingan (60-70) dB (A) tergolong skala kuat yang sumbernya dari kantor bising, jalanan pada umumnya, radio, dan perusahaan.

Masyarakat permukiman RT 11 tidak mungkin dapat mengendalikan kebisingan yang timbul di lokasi penelitian. Masyarakat hanya mampu mengelola kebisingan dengan cara memperkecil tingkat kebisingan secara alamiah, walaupun nilai reduksi kebisingan akibat kondisi di sekitar permukiman tidak terlampau signifikan. Faktorfaktor alami yang memungkinkan mereduksi kebisingan adalah:

a. Permukaan Tanah

Apabila bunyi merambat dari sumber ke suatu titik melalui permukaan tanah yang lunak, permukaan tersebut akan cukup signifikan menyerap bunyi yang merambat, sehingga bunyi yang diteriam titik tersebut akan melemah kekuatannya. Adapun permukaan bumi yang keras seperti jalan yang dilapisi aspal atau taman yang dilapisi paving-block akan memberikan efek sebaliknya. Hal ini terjadi karena permukaan keras tidak menyerap gelombang bunyi merambat tetapi justru memantulkannya, 
sehingga bunyi yang sampai ke suatu titik pada jarak tertentu dari sumber bunyi dapat menjadi lebih kuat.

Di lokasi penelitian, halaman rumah pada umumnya tertutup oleh semen (Gambar 1), sehingga bunyi yang sampai ke komplek permukiman tidak berkurang bahkan akan menjadi lebih kuat.

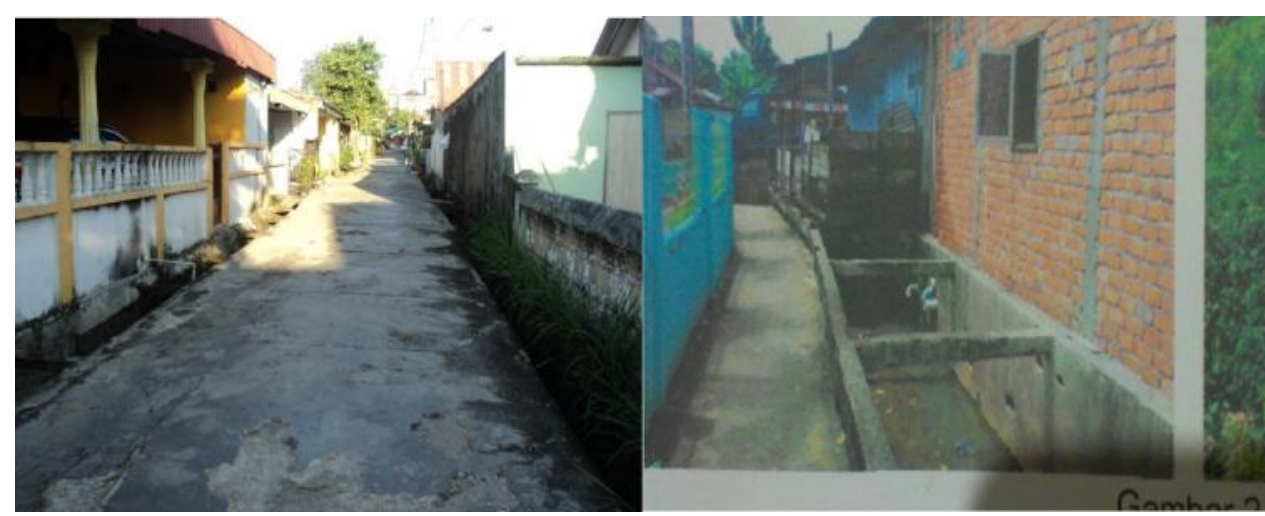

Gambar 1. Halaman permukiman RT 11 yang terbuat dari semen

b. Tanaman

Tanaman merupakan pereduksi kebisingan yang ramah lingkungan dan secara estetika dapat memberikan keindahan bagi lingkungan. Tanaman penyerap kebisingan adalah jenis tanaman berbentuk pohon atau perdu yang mempunyi massa daun yang padat. Pohon dapat meredam suara dengan cara mengabsorpsi gelombang suara oleh daun, cabang, dan ranting. Jenis tumbuhan yang paling efektif untuk meredam suara adalah yang mempunyai tajuk tebal dengan daun yang rindang. Dedaunan tanaman dapat menyerap kebisingan sampai 95\%. Dengan menanam berbagai jenis tanaman dengan berbagai strata yang cukup rapat dan tinggi akan dapat mengurangi kebisingan. Kerapatan daun yang lebih tinggi lebih baik mereduksi bising. Setiap jenis vegetasi memiliki pola frekuensi yang berbeda dalam mereduksi kebisingan.Selain tanaman, rumput juga merupakan salah satu jenis tanaman yang dapat meredam kebisingan, karena suatu permukaan yang ditumbuhi oleh rumput tidak dapat memantulkan suara. Dalam suatu jurnal yang berjudul Environment Benefits of Grass using Grass-Cell Porous Pavers (www.grasscel.com.au, diakses 5 Mei 2016) disebutkan bahwa tanaman rumput memiliki kemampuan menyerap suara sedangkan permukaan keras akan memantulkan suara, permukaan yang ditumbuhi rumput dapat mengurangi tingkat kebisingan antara 20\% hingga $30 \%$ jika dibandingkan dengan permukaan keras yang tidak ditumbuhi rumput. Rumput dapat menurunkan kebisingan antara 8 hingga $10 \mathrm{~dB}(\mathrm{~A})$.

Kajian Tingkat Kebisingan Komplek Permukiman di Ruang Peruntukan Perdagangan Dan Jasa Di Kota Jambi. 
Dengan memanfaatkan 2 faktor alami disebutkan di atas, maka tingkat tingkat kebisingan di RT 11 Kelurahan Solok Sipin akan menurun.

Dalam penelitian ini tidak dilakukan kajian tentang seberapa besar penurunan tingkat kebiisingan oleh halaman rumah yang ditumbuhi rumput, sehingga tidak tersedia data mengenai besaran penurunan tingkat kebisingan bila kedua faktor alami di atas dijumpai di RT 11 Kelurahan Solok Sipin.

\section{KESIMPULAN DAN SARAN}

\section{Kesimpulan.}

Dari Penelitian yang dilakukan dapat diambil kesimpulan sesuai dengan tujuan adalah sebagai berikut : 1). Tingkat kebisingan di komplek permukiman RT 11 di jalan Prof. Dr. Soemantri Brojonegoro Kelurahan Solok Sipin Kota Jambi yang terletak di ruang peruntukan perdagangan dan jasa sudah di atas baku mutu lingkungan, yakni :

(a) Tingkat Kebisingan Ekivalen/Noise Level (Equivalent), $\mathrm{L}_{\mathrm{eq}}=62,4 \mathrm{~dB}$ (A); (b). Tingkat Kebisingan Rata-rata/Noise Level (Average), $\mathrm{L}_{\mathrm{avg}}=62,2 \mathrm{~dB}$ (A); (c). Tingkat Kebisingan Minimum/Noise Level (Minimum), $\mathrm{L}_{\min }=60,2 \mathrm{~dB}(\mathrm{~A})$; (d). Tingkat Kebisingan Maksimum/Noise Level (maximum), $\mathrm{L}_{\max }=64,3 \mathrm{~dB}(\mathrm{~A})$. Semuanya telah di atas baku mutu yakni > $55 \mathrm{~dB}(\mathrm{~A}) .2$ ). Solusi yang dapat dilakukan masyarakat permukiman RT 11 dimaksud untuk mengurangi kebisingan adalah dengan menanam rumput di halaman rumah serta memperkaya perdu dan pohon di pekarangan rumah.

\section{Saran}

Kepada masyarakat agar tidak membangun rumah tinggal di ruang yang bukan ruang peruntukan permukiman.Bila permukiman telah terpapar kebisingan di atas $55 \mathrm{~dB}$ (A), masyarakat permukiman yang bersangkutan tidak menutup halaman rumah, tetapi sebaiknya memperkaya penghijauan atau pohon untuk mengurangi tingkat kebisingan.

\section{DAFTAR PUSTAKA}

Bappeda Kota Jambi, 2013, Peta Rencana Tata Ruang Wilayah (RTRW) Kota Jambi 2013-2033, Jambi.

Menteri Negara Lingkungan Hidup, 1996, Keputusan Menteri Negara Lingkungan Hidup Nomor : KEP-48/MENLH/11/1996 Tentang Baku Tingkat Kebisingan, Jakarta. 
Menteri Pekerjaan Umum RI, 2007, Peraturan Menteri Pekerjaan Umum Nomor : 41/PRT/M/2007 Tentang Pedoman Kriteria Teknik Kawasan Budidaya, Jakarta.

Sumarni, Sri, 2011, Evaluasi Kebisingan PT. Tirta Investama Klaten Dan dampaknya Terhadap Masyarakat Sekitar, Thesis, Universitas Diponegoro, Surabaya. 